\title{
A BRIEF RESPONSE TO \\ 'The Christology OF Titus 2:13 AND 1 TIM. 2:5' \\ BY J. CHRISTOPHER EDWARDS
}

\section{Murray J. Harris}

We can be grateful to Dr Edwards for reminding us of part of the Old Testament background of the ransom logion and for highlighting the similarity of Mark 10:45, 1 Timothy 2:6, Titus 2:14, and Barnabas 14:6.

In its essence, Dr Edwards' view seems to be that the similarities between 1 Timothy 2:1-7 and Titus 2:11-14 are so great that it is unlikely that their Christologies should not also be identical. Then, since $\theta$ cós and Xpiotòs 'Inooũs are clearly distinguished in 1 Timothy 2:5, they should also be distinguished in Titus 2:13. So the common translation that ascribes the title 'our great God and Saviour' to Jesus Christ 'is not valid'.

That there are certain similarities between 1 Timothy 2:1-7 and Titus 2:11-14 is incontestable (although it is perhaps the universal 'scope' of salvation rather than its universal 'extension'), but when we compare the two verses in question, a principal difference between them becomes apparent, namely that 1 Timothy $2: 5$ is concerned with

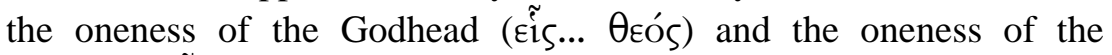

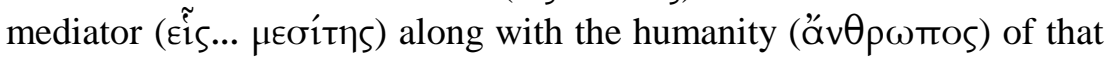
one mediator, emphases that are lacking in Titus 2:13, which could be affirming the complementary truth of Christ's deity (hardly 'a fundamentally different Christology') as well as his glorious appearing as the 'blessed hope' of Christians.

From notes seven and seventeen it appears that Edwards wishes to translate Titus 2:13, 'the appearance of the glory of our great God and

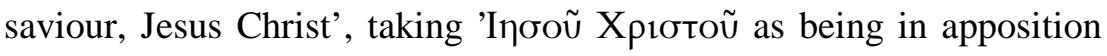

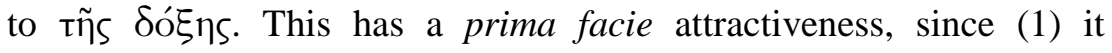
preserves intact the stereotyped $\theta$ Eòs kaì $\sigma \omega \tau \eta ́ p$ formula that was common in First Century religious terminology and always denoted one deity, not two; and (2) it identifies 'our great God and Saviour' as 
the Father, reflecting the usage of the Pastorals (1 Tim. 1:1; 2:3; Tit. $1: 3 ; 2: 10 ; 3: 4)$. Against this must be set three difficulties. (1) While nouns in epexegetic apposition need not be juxtaposed (see Col. 2:2), ĭtıs Éotıv might have removed the ambiguity that arises, ex hypothesi, from the two substantival genitives that occur between

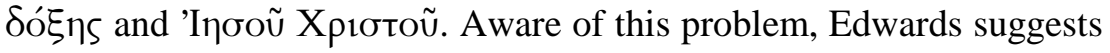

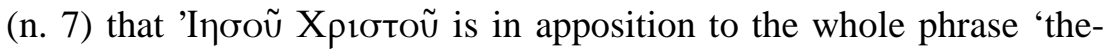
glory-of-our-great-God-and-Saviour', a usage that would be difficult to justify. (2) Since the relative clause that follows 'Inooũ Xpıбтoũ (viz. 'who gave himself for us') defines the work of Jesus Christ as Saviour,

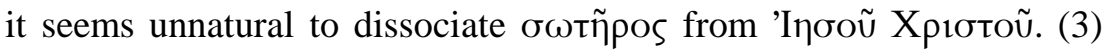
The title $\sigma \omega \tau \eta \dot{\rho} \rho$ is elsewhere applied to Jesus in the Pastorals (2 Tim. 1:10; Tit. $1: 4 ; 3: 6$ ), but nowhere in the New Testament is the title $\delta o ́ \xi \propto \theta \varepsilon o \tilde{~}$ explicitly applied to Jesus.

Also, it is not a little surprising to be told that the common translation that applies the title 'our great God and Saviour' to Jesus Christ, 'is not valid', when almost all grammarians and lexicographers, and many commentators on Titus (from Ellicott through to Marshall, Mounce and Collins), support this translation, not to mention the majority of modern English versions (RV, TCNT, RSV, NRSV, NEB, REB, NASB ${ }^{1,2}$, JB, NJB, GNB, NIV, TNIV, HCSB, Weymouth, Goodspeed, Barclay). See further my Jesus as God. The New Testament Use of Theos in Reference to Jesus (Grand Rapids: Baker, 1992; repr. Eugene, OR: Wipf and Stock, 2008): 173-85. 